\title{
Propaganda as a weapon and a tool of totalitarian power: The image of the concept in the common discourse of the war and occupation years (1939-1945)
}

\section{Introductory remarks and research goals}

The basic publication goals have been indicated in the title. In this article, I describe communication phenomena pertaining to the war and occupation years (1939-1945), which occurred in the parts of Poland occupied by the Third Reich, called in the official nomenclature the General Governorship. ${ }^{1}$ In this paper, I do not focus as much on the description of the semantics or pragmatics of the propaganda language used by the Nazi authorities toward the inhabitants of the occupied country, but rather I try to answer the question of how a collective encounter with the brutal practice of the totalitarian power (with its war and totalitarian discourse), and in fact, in the means of mass communication subordinated to it, was reflected in the common discourse ("non-totalitarian").

Thus, I describe the narrative about the methods and means of hegemonic communication used by the Nazi authorities (texts and forms) (cf. Garlicki, Noga-Bogomilski 2004; Fras 2006; Kamińska-Szmaj 2013), which became established in the "anti-totalitarian" discourse. The form of updating this discourse are journals and war chronicles, in which one can find quite a large collection of remarks

1 The article is part of a series of my publications on war and political propaganda; see Poprawa (2016a, b, 2017). I have outlined the model of political communication, political discourses of 19391945, and totalitarian propaganda more broadly in Poprawa (2016a, 2017) — in these deliberations, I refer in part to the findings contained in previous works. 
about "what, of what and how" a Nazi propaganda communicated. ${ }^{2}$ I am primarily interested in determining what image of mass communication was created, which was used by the occupation authorities, namely how was the propaganda of war and mechanisms of the language of the totalitarian power understood during the "everyday occupation life" (the term is taken from the well-known monograph of Tomasz Szarota, 1988).

I am assuming that the period of the Second World War is not only the first experience of totalitarianism and propaganda in the Polish history functioning as a tool of oppressive action, but also an important time in the history of mass and political communication concepts. War events were reflected then in the semantics of the terms 'propaganda', 'the language of totalitarian propaganda', because in that period the process of their semantic modification (as in the first case) and the process of naming (as in the second case) began. The war, or rather an encounter with the occupant's discourse, with the practices of totalitarian (hegemonic) power, caused, on the one hand, that the pre-war neutral term propaganda entered the sphere of meanings burdened axiologically and connotatively, and on the other hand, the lexical field describing the phenomena of totalitarianism extended its designating references. ${ }^{3}$

\section{Establishing terminology}

In contemporary interdisciplinary research on political communication, the term discourse is more and more often used instead of the term political propaganda language (in its pluralistic or totalitarian version) (see Kamińska-Szmaj 2011, 2013). In the article, I will discuss the language of the Hitlerite totalitarian power, especially its propaganda practices. This results from the assumption that examining them in terms of discourse allows one to look at communication in a holistic way, and above all to show verbal and non-verbal phenomena in a broader context, taking into account the social and institutional order, relations between the authorities and other types of social activity (cf. Poprawa 2012). ${ }^{4}$ In the case of research on political

2 The material was excerpted from the chronicles of: Ludwik Landau, Remigiusz Moszyński and the Moszyński family, Zygmunt Klukowski, Halina Regulska, Maria Bobrzyńska, Bronisława Bobrowska, Stanisław Rembek, Edward Kubalski, and Zenon Waśniewski. All of them do not have the status of omniscient forms of literary nature. What is more - the majority of the chronicles, as we can read from the text frame and dating, were written because of the war, and more precisely: with the intention of providing a chronicle description of events that surprised their creators, and observations of everyday life - also in its brutal version. For full titles with abbreviations, please see the bibliography.

${ }^{3}$ An outline of this phenomenon is discussed in another article of mine contained in this volume of Język a Kultura (Poprawa, Totalitaryzm - doświadczenie i konceptualizacja językowa. Obraz pojęcia w języku polityki okresu drugiej wojny światowej, pp. 137-176).

${ }^{4}$ Similarly, of the properties of the language of totalitarian power, the textual practices for the use of this power - mainly in the form of propaganda, but also other forms - more or less 
texts, it is primarily about showing how the authorities at the level of their appropriate communication practices create the framework of the social world and how the messages in public circulation (especially language and texts) reflect their characteristic visions of political life, the forms of governance, axiologically (ideologically) charged systems of social norms and values, etc. I am particularly interested in this context - understood as the reception of the entirety of messages identified with the totalitarian power, and thus the awareness included in the common discourse (which is updated with journals and war chronicles, cf. Rodak 2006; Niewiara 2010; see also Leociak 2016) of how and for what purpose such communication was used and how it was widely experienced, lived, and conceptualized.

For the purposes of this article - from among the rich definitions of discourse (and the concept of discourse analysis) - I choose the research proposal of Maria Wojtak, who defines the starting term for our deliberations in this way:

A discourse means the entirety of communication practices related to a specific field of human activity [...] it is essentially a way of organizing human activity, and thus a communication practice of a specific community, which in the course of various interactions determines and agrees with contents relevant to it, preserves appropriate scenarios of communication behaviours and the rules for their completion through utterances and/or non-verbal means Wojtak (2010: 81).

Thus, the discourse in this paper will be a category expressing not only the properties of texts and language typical of totalitarian power, but also the term naming its communication practices, which have their institutional legitimacy, because they are used by both the regime administration (in this case for the military and police apparatus), as well as by the media serving the authorities (so they have a primarily propaganda character).

Let us add one more important assumption. Namely, every power - as Michael Foucault and Pierre Bourdieu would put it - establishes an "order of discourse", determining the political culture, the system of communication practices and the relations between the subjects of social, public and political life, and finally the ideology (i.a. after: Howarth 2008; Grzmil-Tylutki 2011; see e.g. Witosz 2009; Poprawa 2012). The relations of the authorities are inherently asymmetrical (unequal), but in the case of regime (totalitarian) power, this hierarchical order adopts a hegemonic and monopolistic shape, that is, excluding any social dialogue. Then, the methods of governance go beyond the limits of legal control, and situate themselves in a continuum that includes domination, violence (physical and psychological) and coercion (after: Scott 2006). The tools of totalitarian power may be different, but most certainly its administrators completely appropri-

institutionalized - and the communication spaces write M. Głowiński (1996) or P. Zemszał (2016: 43-64), expanding the traditional theoretical framework and calling the language of totalitarian power (a.k.a. newspeak) "a totalitarian discourse". 
ate public space and control the private life of citizens. Thus, in the discourse used by totalitarian power, all pragmatic forms take the shape of an extremely marked "rhetoric of domination" (Wasilewski 2006), and semantics expresses a simplified - and frequently fictitious — vision of the world and man (see e.g. Bralczyk 2001; Głowiński 1990).

\section{The war journal as a source of research on totalitarian discourse: Theoretical implications}

War journals and chronicles are not only an interesting starting point to look for traces of common (collective) discourse, but also a document of the influence of other discourses. In this sense, the analysis of journals - in the absence of other reception and behavior research of mass communication auditorium during the war - may be a tool that enables accessing collective receptive awareness on the communication of totalitarian power (and also be a picture of war propaganda "filtered" through private experience). What is more, this is connected in part with new methodological perspectives in the field of research on the reception of mass communication in the broad sense, as well as propaganda in the strict sense. In traditional models of propaganda research or mass (media) communication, a one-way communication process was typically adopted: from the transmission source to the mass reception, and the receiving process itself was interpreted from the 'effectiveness-ineffectiveness' perspective. In other words, the impact of media texts was related to the acting on the intentions contained in the texts, and its measure was to be the receiver's behaviors related to the perlocutionary effect known in pragmalinguistics (as is known, proposed in the theory of John L. Austin on performativity).

Modern research on the reception of mass media modifies this perspective, and what is more, it emphasizes that the communication process does not have to be measured only at the level of the recipient's actions that accomplish the sender's intended purpose, but at the level of experiences and emotional behaviors related to mass communication (see e.g. Goban-Klas 2005; Mrozowski 2001; Stelmach 2014; Pisarek 2008).

The properties of media communication, especially the one - as in the subject I am proposing — which has the nature of "mediated propaganda" (Stelmach 2014), used as a form of influence for the purposes of the totalitarian power and its war policy, are also measured at the level of its oppressive, aggressive ("massed") form. It can be assumed then that just being in an oppressive communication environment, getting in touch with the "rhetoric of domination" (Wasilewski 2006) or "rhetoric of hatred" (Głowiński 2007) causes at least discomfort, and in extreme situations - for example during war - testifies to the activation of the distortion 
function of the language (see Wesołowska 1996). The recipient does not have to change their attitudes and judgments under the influence of such communication in order to feel confused by repeatability, multiplicity and aggressiveness of the message. The act of reception is, in fact, the element of the communication process, which does not come down to only agreeing on the broadcast with its performance (reception). The mass text reception process - after Tomasz Goban-Klas - can evoke at least the following impressions: (1) cognitive (that is, adopting a specific knowledge, accepting opinions and points of view); (2) psychological: feelings and emotions and behavioral changes, sometimes opposite to the purpose of the sender of the text (cf. the typology of Goban-Klas [2005: 241]).

To sum up this theme of deliberations, one can say that the discourse of totalitarian power can be reconstructed not only at the level of the propaganda texts themselves, ${ }^{5}$ but by taking a look at the reception of a communication activity. Therefore, in the case of a hegemonic or ideological discourse, it seems interesting to look at the mechanism of the emergence of a "filtered stream of communication" in the receiving experience. Interestingly, the possibility of describing "totalitarian language/discourse" from the "anti-totalitarian discourse/language" perspective is also mentioned by Polish researchers in the works devoted to political propaganda in its totalitarian variant. At this point, let me make two observations. The first of these can be found incidentally in the collection Nowomowa po polsku by Michał Głowiński (1990), in which the distinguished researcher of totalitarian language presents various universal properties of "newspeak" (in the "from the text to other communication components" perspective), while noting that one could start the description of propaganda properties á rebours, that is, accepting the perspective of the recipient ${ }^{6}$ - what he calls a "sign-like reading of newspeak". The second observation was described in the article published by Anna Wierzbicka in 1990 in a volume of the journal Teksty Drugie. I treat this remark as particularly inspiring for showing the features of Nazi war propaganda from the perspective of its reception recorded in the journals created during the occupation. The linguist writes that we know a lot about the "totalitarian language", while the research of this form of communication

5 Such a perspective would above all consider the analysis of propaganda in terms of its function and strategy, and most of all, the media view of the world created for the needs of its owner (cf. Bralczyk 2001), the mechanisms of influence by means of language, namely, recognizable (or not) intentional components, communication strategies (that is, pragmatic and interactive properties of texts, etc.), and the style subordinated to language and speech functions.

6 This was expressed in the introduction to the volume Nowomowa po polsku: "You can approach newspeak in a twofold way. In the first perspective, the main focus is on the properties of this language, its semantic mechanisms, where the attention is focused on the language itself. In the second perspective, we deal with what I would call a sign-like reading of newspeak. It is treated then as a sign, from which - when it is properly interpreted (by taking into account not only the data directly, but also presuppositions) - you can learn a lot (about social awareness, about the engineering of the authorities). When considered in these categories, newspeak is a great historical, sociological and psychological source" (Głowiński 1990: 7). 
from the point of view of "anti-totalitarian language" has been less popular, that is, the impact of this language on the world, perceptions and attitudes of recipients, and also on the entire semiotic space. Wierzbicka notes that "the official totalitarian language usually produces its own opposite - an underground anti-totalitarian language" (1990: 6). The basic communication mechanism of this phenomenon results from the necessity of "language self-defense", while the phenomenon of antinomy itself, and at the same time the coexistence of "legal"/"official" totalitarian discourse and its opposition discourses (common and dissent) is described by the metonymic term "diglossia". ${ }^{7}$ As is known, on the opposite pole of the totalitarian language, discourses functioning in the "second circulation" may appear (see Kamińska-Szmaj 2013), and under war conditions - especially during the Second World War - it was a "fighting language" (used to mobilize the occupied society, being a form of sabotage, counter-propaganda or political satire, see e.g. Wolińska 1996; Jędrzejko 1996; Jastrzębski 1986). In theoretical and literary works, omniscient forms, such as journals, have various functions ascribed to them, while in part they are everyday communication practice in which private narration results from the dissent of reality. Culture knows many such forms of symbolic opposition, as well as voicing in the journals a critical opinion about what is happening, or the recording of views that cannot be publicly expressed. This phenomenon is reflected in the phrase internal emigration, expressing the attitude of boycott, dissent or reluctance towards the system and culture - treated as hegemonic or as a carrier of authoritarian (totalitarian) power. In this sense, the "internal emigration" attitude becomes the dominant of the narratives contained in the material examined by me. ${ }^{8}$

7 The researcher presents an interesting hypothesis that the anti-totalitarian language is usually given more attention than the official, manipulative totalitarian language. Wierzbicka shows the phenomenon of "diglossia" at the level of Polish People's Republic (PRL) newspeak and the common language or the language of political opposition (actions of opposition), while the term "diglossia" (that is, the coexistence of two communicative circulations) and "language self-defense", she derives from the works of researchers dealing with the language of propaganda in the USSR (called "the Soviet language" and the common/private communication opposed to it). Wierzbicka explains that: "self-defense in a totalitarian or para-totalitarian system consists in finding ways to express (in a more or less constant form) those emotions, attitudes and thoughts which in a country dominated by harsh political control cannot be expressed directly". However, they can linguistically "find expression in 'underground' words and expressions, and this fact can bring to the enslaved people some degree of psychological relief or liberation". In the context of the considerations made in this article, it is worth drawing attention to one more feature of "the language of the second circulation". Namely, as the article of Wierzbicka says, "the underground language (the language of the second circulation) is a form of national self-defense against the effect of long-term brain-washing propaganda. It stimulates 'underground attitudes'; helps to reduce fear and strengthen the power of resistance and the will to persevere" (1990: 6). On this, see also the voices of M. Głowiński and S. Balbus on Wierzbicka's article in Język i polityka (1990).

${ }^{8}$ In Polish culture, the term internal emigration was popularized in the PRL period to name the attitude of Polish intellectuals boycotting the authoritarian power or the newspeak dominating the public circulation and the politicized culture. In fact, this metaphorical term derives from the 
However, let us return to the second theoretical theme. As it turns out, the research on the reception of mass (media) texts is more difficult than the analysis of their content or functional aspects. Many theories on this subject came into being, from pragmatic ones to cultural and semiotic ones. Thusly, the reception of media communication is looked at from the point of view of its pragmatics, that is, the activity of the recipient (their behaviors under the influence of the media), and from the point of view of semiotic processes taking place while receiving the texts.

As Bogusław Skowronek (2013: 119) writes, the reception of the media text is a process of matching various semiotic competences held by users, that is, "cultural protocols (media competences)", which can also be explained as "compatibility (or incompatibility)" of media visions of the world with the beliefs held by the recipients" (2013: 119). In contemporary media study theories, the thesis that resounds more and more is that media communication cannot be limited only to the Lasswellian interpretation of the communication act as a one-way process with the active category of the subject (sender, dispatcher) of the message and the passive category of its addressee (recipient, auditorium) (see Skowronek 2013; Piekot 2006; Pisarek 2008). It results, among others, from the assumption that, firstly, each communication product becomes a discourse, that is, a complex sign structure, a communication event and an interactive process (cf. van Dijk, ed., 2001), and, secondly, every meaning recorded in a media text (transmission) acquires its semantic update only at the reception stage. Let us add that this assumption also applies to texts showing a relationship with the hegemonic power or containing ideological content for the purposes of propaganda (Barker 2005; Mrozowski 2001).

The phenomenon of "an active recipient" - re-evaluating the current view on the course of media communication - is predominately explained by Stuart Hall in the "coding-decoding" model of media discourses established in 1981. The British semiologist, whose findings have contributed much to the analysis of discourses, looks at communication processes more broadly than just as (oneway) action according to the formula: '(active) dispatcher + producer and selector of media message' $\rightarrow$ 'anonymous, mass and passive auditorium'. According to this model, each form of mass communication has a multi-subject nature, and thus the meaning-creating process takes place on two sides of the communication act. Hall's theory influenced not only media study research, but above all, it has changed the cognitive status of the auditorium (recipients) of media texts. In the light of this theory, the recipient becomes the real subject and creator of the communication process, both at the semantic and pragmatic level. The recipient

psychological and sociological research of R. Merton and relates to the attitude of withdrawal from public life, dissent of official life or rebellion against the authorities or their rituals; it is otherwise a form of self-defense against the symbolism and ritual of the authorities. More on this phenomenon in: Garlicki, Noga-Bogomilski (2004: 162-173). 
is treated as a "conscious producer of meaning" and "content selector" (Barker 2005: 375). This is due to the fact that no communication intention in the pragmatic sense guarantees the kind of reception which would be the intention of coders, and what is more, the messages are always polysemic: one can say that, first of all, they become intertextual (interdiscursive) when they are read out, that is, they are always subject to multiple interpretations. The recipient may — in contrast to the sender - not only notice a "hidden meaning" of communication, but above all, always refer every text in the receiving experience to the communication situation and the entire background of the interaction of other discourses. A very important observation emerges from Hall's model: the recipient always decodes the message, giving it real meaning, whereas this meaning is consistent with the sender's intentions (hegemonic reading), or completely contradictory to them (oppositional reading).

\section{War and totalitarian discourse versus the anti-totalitarian discourse: A special case of political communication}

The discourse of Hitlerite power (both propaganda and administrative, bureaucratic) revealed itself as a consequence of military operations, the practice of communication with the citizens of the occupied state, as well as a form of warfare, using social engineering tools and psychological total propaganda. Immediately after the September defeat (after the emigration of Polish political and military authorities) Polish institutions were taken over - first by the army, then by the German administration and police apparatus, and on October 26, 1939 the formation of the General Governorship with the capital in Kraków was proclaimed. Governor Hans Frank resided in the city until the end of the war, as well as the so-called General Governorship government. German military authorities quickly eliminated Polish publishing houses and editorial offices, taking over their property. They were replaced by press publications in Polish, completely carrying out the intentions of the information and propaganda policy of the Third Reich. From the very beginning of the occupation - instead of the pre-war, greatly diverse press discourse newspapers were in the services of the occupant, as well as other mass media, over which control was taken by the "local" propaganda office in Kraków subordinate to the Berlin Ministry of Propaganda (completely managed by Joseph Goebbels). From the autumn of 1939, a network of street speakers appeared around the country, broadcasting twice a day messages in accordance with the Nazi point of view, and a year later - each film screening in the cinema was preceded by a documentary series "Tygodnik Dźwiękowy GG". In both cases, rationed information, developing slogans and theses developed by propaganda institutions subordinate to Goebbels, 
became mixed with administrative (addressed to the General Governorship citizens, to the local population) and with war announcements prepared by the propaganda agencies of the Oberkommando der Wehrmacht (OKW) (more on this subject in: Poprawa 2017).

Moreover in 1940 an absolute prohibition against the use of radios was introduced in the entire German-occupied Poland (failure to comply with this regulation was severely punished). What is more, in the autumn of 1939, a permanent element of semiotics in the public space became poster pillars with regulation orders of German authorities, police and military messages (with lists of hostages or names of people shot in mass executions), and propaganda posters - with the clear political insult and the rhetoric of hatred directed against all those whom totalitarian propaganda apparatus linked to the category of an "objective enemy" (cf. Arendt 2008). Demonstration parades of German troops and monstrous expositions of Nazi symbolism were another symbolic form of the ritual of the totalitarian power, expressing not only the intention to legitimize the new order (cf. Szarota 1988; Głowiński 2000), but also "the rhetoric of domination" communicated in a non-verbal way (Wasilewski 2006).

The entirety of the communication practices emerging in the discourse of 1939-1945 was influenced by the whole political and legal context, that is, the state of occupation. The official political propaganda changed its dispatcher, and in addition, the pre-war sovereign order of power, based on the two-way relationship between "the ruling" and "the ruled", changed into a hierarchical (hegemonic), one-way system of influence of "the occupants" on "the occupied" (according to the policy of Hitlerite authorities, but contrary to Polish and international jurisdiction) (cf. Chrobaczyński 2015). The violation of the natural legal order and the introduction of institutional structures of war and totalitarian power (the Third Reich) led to the formation of two communication circulations. The first - from the aggressor's point of view, decreed as legal/official - included the entirety of messages for the use of the military and administrative-police apparatus of the Third Reich, along with its subordinate monopolistic (propaganda) media system. The second was based on the natural communication of the occupational society, while all the public and institutional messages representing the sphere of Polish politics, culture, law, science, etc., went into the illegal/unofficial circulation (according to the laws of occupation), that is, underground (conspirative), and only in this form did it play the actual role of an institutionalized, multi-entity, mainstream of public communication.

These difficult communication relationships are commonly perceived as a clash of two worlds: the occupational power and everyday (also underground) life of citizens in the occupied country. It seems that the bipolar (and at the same time two-entity) communication space can be seen as a distinction between (1) the war and totalitarian discourse of the occupant and (2) the discourse of the occupied society. The first of them - as has already been proposed above - con- 
stituted a one-way stream of official messages of the totalitarian power towards citizens, primarily expressing the intent of control and coercion, and secondarily informational, administrative and cultural purposes, in accordance with Nazi doctrine and the policy of the Hitlerite power apparatus. The second one included the entirety of messages from the occupied society: it expressed in Polish the sphere of values, communication needs, culture, and above all the diversity (multi-entity) of discourses: common, public, political, media and other (cf. Poprawa 2016a, b, 2017). Thus, the entire communication reality during the Second World War in occupied Poland was bipolar, that is, based on the mechanism of "diglossia" — as metonymically described by Wierzbicka (1990).

The politics of war influenced the linguistic politics of the occupiers, which was connected with the assumed - albeit led differently in various zones of occupation - "fight of the occupants with the Polish language" and "the withdrawal of the Polish language" as a result of "administrative and hostile actions of the occupiers" (Bajerowa 2003: 13). Polish did not disappear from the official communication circulation everywhere - for example, it was not forbidden in the General Governorship, but in the official circulation, rationed by the occupant, it lost the status of the language expressing in a natural way the cultural and national identity. If it appeared in it, it was usually in the form strictly controlled by the Hitlerite authorities (that is, censored) or as the language of translation and the language of mass communication in the services of the occupant (cf. Kleszczowa 1996b). This was related in part to the brutal form of degradation of the Polish culture and the pauperization of the Polish social and cultural life (i.a. Majewski 2015). The totalitarian voice of the occupant stood out in the official space - in symbolism in an aggressive manner manifesting foreign ideology (Nazism) and German war politics. A vivid language, fulfilling its culture-creating and social function, as well as other phenomena of social life, went underground (see Stępnik, Rajewski, eds., 2011). Only in private and/ or conspiratorial conditions could it fulfill its most important functions. The policy of the language of the occupant led to the creation of language defense mechanisms, and their forms and functions emerged with the creation of underground life.

The linguistic or cultural policy of the Hitlerite authorities contributed to the degradation of the Polish language - its goal was to completely subdue the language through oppressive communication conditions. It was supposed to be a "utility" language or an administrative and information communication tool. As has already been described, the former pre-war media disappeared. Instead, surrogates of public discourse were created, whose prototypical update was the (Nazi) press in Polish, entirely at the disposal of the German authorities and adapted to the propaganda strategy of the Third Reich, which had already been shaped from 1933. Since this press — as an available medium of information — faked a relationship with the Polish journalistic and opinion-forming tradition, and in fact only used the graphic design of the old newspaper, it did not inspire confidence. It does not mean it was not read - it was quite widely available, it had a large circulation and a very low price (al- 
most at an unchanged level - despite the raging war inflation) (cf. Głowiński 2000; Woźniakowski 1997, 2014; Bartoszewski 1986; Cytowska 1986). This press, therefore, served as a propaganda tube, as well as a poster pillar (in a more or less commented form, it passed increasingly restrictive orders, prohibitions, administrative orders). As a universally recognized "voice of the Hitlerite authorities", it was also widely depreciated. A widely recognizable contemptuous and metonymic lexicon of the war usage expressed this attitude, for example: reptile press, rag press, rags, filthy tabloids (in Polish language: prasa gadzinowa, gadzinówki, szmaty, szmattawce) and many others (more on this in the analytical part of the article, cf. Poprawa 2017).

The language and information policy of the occupant was connected with the intentions of the cultural policy in the broad sense, revealing its connection with the ideology of national socialism. Now, the occupied Polish territories were recognized in the Nazi discourse as "a strange administrative creation", "a quasicountry", "an area of colonization and exploitation" of the Herrenvolk in relation to its citizens with the status - according to the race doctrine - of Untermenschen (see i.a. Szarota 1988; Madajczyk 1970; Bartoszewski 1987; Głowiński 2000; Winstone 2015). The cultural policy guidelines introduced already in 1940 (entitled Kulturpolitische Richtlinien), published by the Department of Propaganda of the General Governorship, prohibited the cooperation of Germans and Poles in the field of cultural development; they were segregationist in nature since they banned the publication of "German masterpieces and world view books" in Polish and their use by Poles (after: Kleszczowa 1996b: 26). Occupational German legislation, practically in every sense based on a racist vision of the world and national socialist ideology, allowed Poles to communicate in the General Governorship in their own language, but only within the limits imposed by politics and administration, mainly for pragmatic purposes (official, professional, casual). The pauperization of the Polish language, the limiting of its status, and predominantly, the lowering of its rank as a carrier of socio-cultural life (scientific, educational, as well as literary, etc.) meant that Polish - as Krystyna Kleszczowa writes "though not banned from use by Poles, was threatened not so much in its existence, but in its form. It was meant to exist as the language of low-cultured people, basically of ordinary workers [...]" (Kleszczowa 1996b: 28).

\section{The image of the war and totalitarian discourse in the occupation journals: An attempt at analysis}

\subsection{Symbolic violence as a practice of totalitarian discourse}

The most important experience of German totalitarianism in the occupational journals concerns terror as a common component of the "occupational every- 
day life" (Szarota 1988). Above all, journal writers are paralyzed by the common awareness that every citizen is exposed to the danger of the Hitlerite militarypolice apparatus (especially the Gestapo and SS units). The imposed occupation system, and predominantly the communication ritual of the Hitlerite authorities ("the order of Nazi discourse"), appears as a form of "conscious and planned ruling by the authorities over the space of social communication" (Nowak 2008: 210). On the one hand, it provokes resistance (dissent), on the other hand, it is troublesome, because every form of the manifestation of power (the new unacceptable system), is perceived as psychological and symbolic violence. This function - in a common collective sense - is played by both the Hitlerite monopolistic propaganda and new communication rituals in the public space. Not only are they perceived as theatralization of power, but also as a form of degradation of the Polish culture. The monopolistic and directive communication of "the occupiers" addressed to "occupied" was revealed in September 1939, when the army, the civil administration and the police apparatus of the conquered areas of the Second Polish Republic were being taken over. Before the Polish society learned to read the signs and forms of propaganda, the performative force of the administrative and police discourse had revealed itself. The discourse was made known by introducing new genres into circulation and collective consciousness: the icons of oppressive actions and the semiotic code of hegemonic power (see Czerwiński 2015). Initially, in the public space, information and official messages appeared that took the form of orders, bans, commands or cautions. Above all, collective emotions were strongly affected by the first announcements of collective death sentences carried out on citizens of the Polish state for activities that — in the light of the law of the occupant — were considered illegal. The adjective illegal became the keyword for many announcements of Nazi authorities, and information on judgments, punishments were one of the most recognizable symbols of official communication until the end of the war. A small illustration of this can be found in this fragment from the chronicle of Remigiusz Moszyński:

The first announcement in red on the street: "Attention! A worker was shot dead for illegal weapon possession [...]" This first judgement made an impression, although because of tomorrow — the Independence Day, I expect something similar (ReMosz, 10.11.1939, p. 66).

The indicated 'regulations, posters and messages of occupation authorities' are usually interpreted as a symbolic addition to the real occupational terror and a sign of monologue (regime) communication directed against the interests and will of the occupied society. The documents signed by the German authorities (of the General Governorship, military, occupation) hold the most important place in the public space and formally become a bunch of various oppressive (directive) content, as well as a sign of the bureaucratic-police apparatus of the General Governorship authorities. They took the form of various types of texts addressed to the collective addressee (announcement, regulation, poster), but in 
principle with the recognizable illocutionary directive (appeal, notification, order, duty, regulation, guidelines) and the textual frame (genre name) (cf. Bartmiński, Niebrzegowska-Bartmińska 2009).

The authors of the journals who, at the same time, are recipients of the communication, are paralyzed not only by the contents, but also the variant form, often expressing directive intentions (of command and prohibition) in a flashy visual layout. What is more, the authors learn to read this code (e.g. the functions of the colour of ephemera, the modality of visual signs). The source material reveals numerous textual patterns that are associated with the voice of hegemonic (total) power - as Eugeniusz Cezary Król (2015) would describe it - with the use of the vocative form "against the conquered". It can be assumed that longer references to these textual events are also a perlocutionary effect of the communication act which implies negative feelings and emotions. This is evidenced by the lexical exhibitors of fear recorded in the journals (e.g. horror, hatred, fear) or predicates describing the feelings accompanying the reading of these regulations (e.g. $\mathrm{X}+$ it caused a stir/confusion, read with concern, life gets ugly).

Let us look at several longer examples contained in the journals, reflecting the process of receiving "the language of total administration" (this term was popularized by Herbert Marcuse, 2003). The authors of the journals primarily categorize them:

- by drawing attention to the genre pattern and its visual (graphic form) and exposing the pragmatics of the voice of the dispatcher of totalitarian power (cf. Wasilewski 2006), for example: regulation, poster, announcement + pink, red, bright colour. Compare:

They announce using red posters that a regulation is to be issued so that in the event of an air strike alert, the Polish population would gather on the squares (StRemb, 4.12.1943);

The pillars had new, large red posters glued, with an appeal to all "men and women" saying that "the patience of the Germans is exhausted" and that for hiding and cooperating with "robbers and bandits" they will burn and destroy entire villages (ZKluk, 19.09.1942, p. 296);

The newspaper stands had red sheets of posters with the date of 1st of September glued calling for contributions for winter help in fierce battles against "wild bastions", as Hitler calls the Bolshevik army (EdKub, 17.09.1941, p. 162);

Today brightly colored posters have been blown in the city with a call for the broader population, for men and women between the ages of 16 and 50, to apply voluntarily for agricultural works in Germany [...] This announcement caused an understandable commotion among the interested parties (ZKluk, 7.02.1940, p. 100); 
— by pointing out that each of these street texts, announced by various institutions of the totalitarian apparatus (district governor, police chief, generalgovernor, etc.) is a document of terror against the Polish society.

In the latter group, there are descriptions of violence used by the occupant (e.g. resettlement to the Reich/for agricultural works in Germany, winter aid contribution, confiscation of property), punishments (burn, destroy entire villages, "round-ups in the street", fine, arrest, execution by shooting). It is also about the propaganda creation of the alleged "enemy" (in the official Nazi discourse, these are: secret organizations referred to as "bandits and brigands"), compare:

Posters of the head of police are hung everywhere, calling on the population to fight secret organizations or landing troops (StRemb, 10.12.1943);

Today posters with the proclamation of the general-governor appeared in the city, and apparently in the Wola district, there was a "round-up" on the street "for works" (LLand, vol. 1, 4.05.1940, p. 453);

A new announcement or order has been glued today [...] Each order contains threats of various punishments, fines, arrests, executions by shooting, etc. Obviously, in those conditions life gets ugly (ZKluk, 9.11.1939, p. 70).

The greatest source of anxiety, rumors, but also rebellion are printouts informing about the brutality of the Hitlerite apparatus of violence (posters announcing the execution of sentences, execution orders/lists of the executed, announcements of death sentences), as in, for example, the following fragments of chronicles:

At the same time, posters announcing the execution of sentences on "the bandits", who robbed Polish people of food and clothes. Bitter irony - Germans as judges of the bandits! (BrBobr, 27.01.1940, p. 47);

The occupants in Warsaw announce new and new execution orders/lists of executed hostages. Weapon possession - death, scrap trade — death, hiding Jews - death. Whatever the reason, death, death, death is imminent. Warsaw, however, does not pay any attention to these announcements (LKrModz, p. 49).

In the journals, as well as in the entire "non-totalitarian" discourse, functioning in the second circulation (in its dissent, common and ideological-political forms connected with conspiracy), the image of terror perpetuates, and the vocabulary of Polish stands out with words naming acts of violence by the occupant. The research material contains a very rich collection, therefore, here we should mention only those that appear in the commentary form attached to the description of the communication practices described above. These are mainly: (1) verbs naming police actions: transport away, frisk, check identity papers, execute by shooting, torture (by the Gestapo and SS men), or action nouns motivated by them, often in plural forms, for example (mass + ) arrests, executions, executions by firing squad, displacement, frisking; (2) neosemantisms such as recruitment, 
round-up, manhunt (sometimes written in inverted commas); (3) pictorial/vivid collocations such as: transport away for works (three batches of people), take people away (straight from the street), organize a manhunt, guard all entry roads, raids with numerous checks of identity papers; arrests are ongoing/have grown extensively; common/"indiscriminate", "straight from the street" arrests. The lexis describing acts of violence (terror) also has its metonymic versions, whose source domain is PHYSICAL FORCEFUL ACT, connoting violence both in the meaning of PHYSICAL VIOLENCE ACT, and PSYCHOLOGICAL VIOLENCE ACT (collective emotions), for axample: A manhunt unknown in the history of mankind; a blow directed at someone; a terrible blow; a blow to the head with a blunt end; torment inflicted alive; paddy wagons were transporting away a plentiful harvest. Relevant in relation to these measures are exponents of negative feelings and moods: live in constant fear, be afraid of own shadow, something keeps people tensed/electrifies the population; nobody knows who will go next; lawlessness rules us; live as if corked in a bottle; people mope about; time passes filled with poverty and apathy. All the more so since they result from the author's reflection on the reported - unexpected and surprising because of their horror - facts of occupation violence (testimonies of extermination and Shoah). The latter are:

1) recorded in chronicles as knowledge acquired from rumors or forms of whisper propaganda (or from underground publications) - they stand out on the metatextual level as a frame situating them within the scope of common communication/narration (cf. Wyrwas 20149\%; Poprawa 2016b):

People says that a few days ago Germans gassed again around 300 people at Majdanek. Special death houses (the so-called Gaskammer) were built for that purpose (ReMosz, 30.03.1943, p. 360);

Terrible news come from the Majdanek camp. What are these German murderers doing! Over the past few days, 6,000 people have been shot dead! (ReMosz, 11.05.1942, p. 278);

Entire train wagons with Jews arrive at Bełzec and they disappear there without a trace. Nobody knows what is being done there. Probably new murders from the hands of the Gestapo (ReMosz, 6.04.1941, p. 175);

The Germans celebrated the Epiphany in their own way: executions took place at the Jewish cemetery. They ordered Jews to dig graves for the executed Polish intelligentsia and hence this news in the city (ReMosz, 7.01.1940, p. 82);

2) recorded as a personal testimony or participatory self-observation, sometimes stylistically expressing a commentary of journalistic provenance, which re-

${ }^{9}$ It seems that such a modality, recorded in narratives, carries out a frame pragmatically relevant to the communication acts of the warning, which K. Wyrwas attributes to the common stories, explicating also the judgment contained in it the following way: "I am telling this story so that you know what to do and what not to do when similar things happen". 
sults from the fact that a journal record is a daily practice of communication of people often involved in underground activities (in its propaganda and political form), for example:

Life brings strange surprises these days. Right now a war is going on around $u s$, a real war, with mutual shooting, starting fires, even with tanks and some small cannons - the modern "Jewish War" with episodes worthy of the pen of a new Joseph Flavius (LLand, vol. 2, 20.04.1943, p. 355).

This is how the Warsaw ghetto uprising (April-May 1943) was described by Ludwik Landau - not only an outstanding war chronicler, but also an activist of underground socialist organizations (PPS-WRN) and author of reports prepared for the needs of the Polish exile government.

\subsection{The propaganda ritual and forms of total (mass) propaganda}

Different emotions are also aroused by the widespread propaganda ritual and its massive, ubiquitous form. Eye-witness observers - the addressees of Nazi propaganda texts - record numerous utility texts and fleeting printouts with the impelling function. Their comment is partly a sign of perlocutionary effects. Although in general there is no evidence in the material indicating that the propaganda dispatcher managed to mobilize people to activities consistent with dispatcher's expectations, the propaganda invariably had its effects in the psychological layer, because it triggered negative moods or even aesthetic impressions. The mere fact that it occurred in the form of an endless ritual, was onerous. In the genological awareness (cf. Zaśko-Zielińska 2002) of the authors of the journals, the following textual patterns were recorded:

1) primarily subordinated to inform on military activities (usually as OKW materials adapted to "the propaganda point of view", that is, military communiques and reportages addressed to the Polish recipient, visual forms and broadcasts prepared by information headquarters of the High Command of the German Armed Forces - called war communiques, (audio) war weeklies, war chronicles by journal writers;

2) ephemera, containing mainly the exhibition of the most important slogans of an agitational nature (e.g. expressing the Nazi doctrine or the typical slogans of the totalitarian propaganda language against the "enemy", which in the Lingua Tertii Imperii (LTI) version translated into Polish took the form of a witch-hunt based on racist, anti-Semitic or anti-Russian content) - the patterns of these genres were perceived by the authors of the journals as agitational/propaganda writing, sticker, brochure, poster, affiche, catchword. ${ }^{10}$

10 These were usually various intertextual versions of Tagessparolen 'catchwords of the day', that is, biased forms of the Nazi 'message of the day', an information agenda probably prepared in 
The propaganda repertoire also includes typical agitational-mobilization genres (usually with war and political themes and always characterized by ideological content or the language of contempt). These are:

3) appeals to "the Polish society" (the quotation indicates the euphemizing of ethnonyms introduced by the authorities); or

4) leaflets left in public places (and often even in public buildings, such as schools, shops).

War chroniclers draw attention to their mass, repetitive, intertextual form, consisting in the alteration of the same catchwords in a different genre or visual frame. This last propaganda form appears in 1939 and intensifies during the defeats of the German army, during the offensive of the Red Army and the expected end of the war. At this point, let us look at a few longer fragments of records, showing not only the attitude to the propaganda activities of the occupant, but also the way of the "sign-like reading" of the routinized LTI topoi (cf. Głowiński 1990):

1) for example, Stanisław Rembek, writer and journalist, describes his impressions after the screening of a chronicle (probably the "Tygodnik Dźwiękowy GG"), which was "obligatory" before the film screening:

In Milanówek, however, I have gone to the cinema for the first time in two years. The war weekly was so shocking that I could not sleep after watching it. Battlefields with piles of corpses shot by the Bolsheviks in Lviv were shown [...] Against this background, a stupid costume film made a depressing impression (StRemb 1.09.1941);

2) whereas in the chronicles of Ludwik Landau and Remigiusz Moszyński, a reflective commentary on the cynical content and virulent form of Nazi propaganda reveals itself, in which racial and anti-Semitic clichés were used in various forms (a stereotype of "the enemy" amalgamated into "Judeo-Bolshevism" or in metonymic forms of dehumanization of Jews - these are key words to the Nazi rhetoric, which did not cease even during the Holocaust):

Another manifestation of propaganda in this direction is a poster that appeared today in the city saying Who rules Russia today? Listing properly selected names, the poster gives the answer to this question: "Jews, Jews and only Jews". Deeds follow the Hitlerite propaganda. The fights in the ghetto are dying $[\ldots]$ The Germans, however, promise to themselves that destroying Jews and burning the ghetto will even win them the sympathy of the population - which now more and more often reacts indignantly to German atrocities (LLand, vol. 1, 12.05.1943, p. 409);

person by Goebbels and appropriate PROMI cells. They were disseminated by local branches of German propaganda in the General Governorship, see E.C. Król (1999, 2015), T. Głowiński (2000) and P. Kołtunowski (1990). LTI - Lingua Tertii Imperii - term of Victor Klemperer and a title of his book (ed. 1947). 
Posters were put up (Führer's proclamations are not enough, they must be strengthened) with a bearded Jew wearing a skullcap, and a large louse crawls into his mouth and a writing states: "Jews, lice, typhus". These posters were distributed in schools in two copies ${ }^{11}$ (ReMosz, 23.06.1941, p. 194). ${ }^{12}$

Visual forms, in turn, are variants of the Nazi propaganda discourse, which were practiced as a mock-up of feature films displayed in the Third Reich and as chronicle material that usually preceded screenings at cinemas (cf., i.a., Król 2010; Ociepka 1999; Woźniakowski 1997). Journal writers also note and ridicule the lie contained in such materials, and above all, the activities of propaganda officials (and military units), which consisted of forcing passers-by to be extras in "set-up" propaganda materials. This relatively frequent practice is mentioned in the chronicle of Remigiusz Moszyński, whose author exposes the lie contained in propaganda materials [example 1] or the manipulation consisting in matching makeshift "scenographies" for the purposes of a chronicle or recruitment action [example 2]. Compare:

[1] At Krakowskie Przedmieście [in Lublin - M.P.] a German car full of bread arrived and distributed it to the population, filming it for propaganda - oh, how magnanimous they are and what hunger is in Poland (ReMosz, 7.12.1939, p. 72);

[2] A kilometre long queue is in front of the tobacco shop. The Germans are photographing the scene and call it queues of workers going to the Reich (ReMosz, 24.02.1941, p. 175).

11 The author of the journal, Remigiusz Moszyński, thoroughly discusses the propaganda features of the poster with his son, disturbed with its contents and form, and above all, that the poster has been distributed at school. The son was Leszek Moszyński, a later linguist and in the chronicle written during the occupation a co-author of many reflective notes on the topic of propaganda.

12 The examples of prints and posters (verbal and non-verbal acts of iconic/symbolic violence) noted by Remigiusz Moszyński and Ludwik Landau date back to the period when the Jewish population was condemned to death by the Hitlerite apparatus of terror, with closed ghettos already in place, another most tragic stage of Holocaust was beginning. The Nazi propaganda circulated numerous slogans containing various defamatory and degrading language formulas and content, including posters, satirical drawings and medical metaphors (parasitic, cf. Kołtunowski 1990: 119-121), taken straight from the leading Nazi racial weekly Der Stürmer, expressing aggression, and above all verbal topics used to dehumanize Jews. On various means of racist, anti-Semitic hate speech, see: Wasilewski 2006 (on metaphorical domains expressing the Nazi slogan "Der ewige Jude"), Reisigl (2010) (on dehumanization/reification strategies included in metaphorical language in the general sense, also with examples from the Nazi discourse); also on the forms of euphemizing of the "final solution" as an example of "hidden aggression" see Głowiński 2002: 270. The entire semantic and lexical field serving the euphemizing of the Nazi code name Endlösung der Judenfrage in newspapers published for the Germans living in occupied Poland is discussed by Kołtunowski (1990: 105). It is worth noting that this exceptionally brutal rhetoric also appeared during the Warsaw ghetto uprising (as can be seen in the excerpt from the occupation chronicle of Ludwik Landau), that is, when the Nazis murdered most Polish Jews in the extermination camps. 
The distinguishing feature of totalitarian discourse is propaganda ritualism. On the one hand, it manifests itself at the level of collective communication behaviors (manifestations, ceremonies) that are to express a mechanism of social control, legitimize the actions of the authorities, and manifest the ideology, showcasing its slogans in the form of symbols and collective celebrations (cf. Rothenbuhler 2003; Scott 2006). Due to the emotive style, as well as the form - evoking collective experiences - the spectacles of the totalitarian authorities are oftentimes identified with practices appropriating sacred formulas and for this reason the entire sphere of symbolism and performative behavior is also called "a secular religion" or "a political religion" (terms of Jacques Ellul and Raymond Aron, see Dytman-Stasieńko 2006; Jacko 2008; Allbert 2008). The ritual practices in the totalitarian discourse are, on the one hand, a form of indoctrination and legitimization of the hegemonic power, and on the other hand, a social engineering tool to show that its usurpative nature is unchangeable. This was also the role played by the elements of Nazi symbolism and the spectacles of the Hitlerite power in occupied Poland. Their rhetoric was exclusive to "the occupied", it was - as Marek Karwat would call it - "a peculiar perpetuum mobile of terror", and at the same time, it was aimed at "symbolic, eloquent demonstration of who rules here" (Karwat 2014: 239). If we assume that the Nazi semiotics and celebrations served as secondary elements of war propaganda, they were intended to weaken the morale of the people living in the conquered state and to demonstrate that fighting and resistance make no sense (Jarecka 2008: 117).

Ritualization also applies to the language and repetitive content contained in the form of catchwords and (political) slogans that become the essence of the ideological doctrine. On the ideational (semantic) level, these are usually statements deprived of references, non-predicative, deriving from ideological dogmas, axiology, which the propaganda is addressed to (Bralczyk 2001; Ożóg 2008). On the pragmatic level, presuppositions in a magical way are to prove that what they refer to is not subject to any discussions, because it is shared by the collectivity.

Therefore, the ritualism of propaganda - along with theatrical activities and symbolic iconography demonstrating the ideology (cf. Jacko 2008) — is revealed in the sphere of verbal behaviors. It is considered one of the most important components of the totalitarian language (newspeak and LTI) (cf. e.g. Głowiński 1990; Bralczyk 2001; Dytman-Stasieńko 2006). In the pragmatic sense, it is to create a new reality, magically express the break with the past and manifest new ideas (Nowak 2008). The verbal form of ritualization becomes repetitive, template and routinized catchwords, slogans, clichés, containing a top-down interpretation of the world - in the spirit of the dominant ideology or according to the needs of propaganda dispatchers. Even if they do not have the desired effect, do not affect the recipient relevant to their appellative form, they are, however, performative, causative in that they impose the framework and linguistic exposure of the world with which the recipient does not have to identify, but which is symbolically (iconically) revealed 
to them. The ritual "newspeak element" draws from a template, it is an expression of linguistic poverty and repeated conventions, and therefore its form serves only to mark the communication space. This conventionality does not have to convey meanings but is there to carry out a performative function in the sense that - as Paweł Nowak explains vividly - it can "cloud the communication channel", that is, "not allow other content, undesirable from the point of view of authorities, to appear in the communication space" (2008: 223). Its aggressive form is simply irritating.

The authors of the journals express their contempt for the Nazi symbolism, the administrative ritual and the speeches of dignitaries, and above all the collective behavior of the military. These collective or public symbols and the communication behavior are interpreted as an expression of domination, a collection of props of the totalitarian power, and above all a form of degradation of Polish tradition and culture. They evoke both reluctance, boycott, mockery and in the first period of war - surprise and dread. The symbols of occupation are flags with a swastika, banners, and their excessive use (streets flying with banners, a city decorated with flags). In the narratives contained in these chronicles, the Hitlerite symbolism, which is not surprising, evokes negative feelings and attitudes. Their authors, however, can read the meaning of rituals, and even relate their form to a specific event. A specific expression of ridicule is the scenography accompanying military parades (victorious troops), parades and pageants and host visits (and inspections) of Nazi stewards or arrivals of distinguished guests. The subject of mockery is the main "hero" of the propaganda ritual — the governor Hans Frank, who in his self-presenting acts (speeches addressed to the Poles) poses as "a providential host of the General Governorship", "a tribune of the people" (for example during the annual harvest festival), and he decorates the headquarters of the occupation authorities (Wawel Castle) - as if a crowned ruler - with illuminations, spotlights, and lights. The following selected examples reflect this:

On the walls of the city [Kraków - M.P.] flags with a swastika appeared. The Main Square and Sukiennice are full of them. They look like fresh, bleeding wounds (BrBobr, 30.10.1939, p. 28);

Our local sensation is Frank's arrival. The streets, per "calls with orders", are decorated with banners. Preparations, as is heard, consisted of quite numerous arrests (LLand, vol. 1, 5.10.1940, p. 723);

At aleje Ujazdowskie street, closed off by the cordon of the German military police, the military parade of the victorious troops is greeted by the Führer Hitler himself, who enjoys the parade as Caesar enjoyed his triumphs [...] Citizens hear ceaseless drumrolls and orchestras playing. Street police officers are running through our street with flushed faces (LKrobModz, 5.10.1939, p. 30);

Yesterday's "royal" speech of Frank at Wawel Castle was short, colourless and without typical buffoonery (EdKub, 26.10.1941, p. 172). 
In occupational journals, a clash with these rituals, which are a manifestation of the totalitarian power, as well as propaganda announcing a new order, reconstruction/construction of the country, reforms, improvement of life and situation of the Polish population/benefits for the population for the General Governorship (wording from the chronicle of Ludwik Landau), usually appears as a painful experience (e.g. an analogy of the red colour of the flag with swastika = fresh, bleeding wounds). Nonetheless, examples of a parody of totalitarian discourse also appear to be a permanent practice (cf. observations of Balbus about "the parody of newspeak", 1990, expressed by means of irony or biting commentaries (our local sensation is; the Führer - as Caesar himself, Frank's "royal" speech), implementing a typical "language self-defense mechanism", as well as a common, creative form of "the anti-totalitarian language" (Wierzbicka 1990), present in the occupation humour, which - as Zbigniew Jastrzębski (1986: 168) writes — "bounced off the enemy's catchwords with a comical ricochet".

Ritualization has its forms not only on the level of meanings contained in symbolic forms or in the messages with an impelling and appealing function. Its distortive character manifests itself in nominative measures, which - in the intention of the Hitlerite authorities - consist in deliberately supplanting the Polish language from the public sphere, reducing it to the form of common message, a second-grade language in relation to German, which - of course - results from the basic principles of the occupant's cultural politics (cf. Bajerowa, ed., 1996; Kleszczowa 1996b; Madajczyk 1970). This, of course, connects with the arbitrariness of meanings inscribed in the structure of totalitarian discourse. The journals have not only a common, negative attitude to the imposed administrative terminology, for example, aversion to the name Governorship (General Governorship) (usually its "foreignness" is marked with inverted commas or preceded by the metatextual so-called), but also to neosemantisms or German variants of toponyms commonly recognized in Polish culture (especially those that are names of capital cities or former royal cities):

- "the Kraków castle" instead of Wawel Castle: "Wawel (the use of this name was forbidden, now it is to be "the Kraków castle") evacuated (BrBobr, 5.11.1939, p. 30);

- Lemberg, Warschau instead of Lwów, Warszawa: "And 'the filthy tabloid' announces enrolments for courses in the city of... Lemberg! To the 'Warschau' oddity in Polish texts, we became accustomed, constantly encountering it!" (LLand, vol. 3, 5.08.1943, p. 115);

- Krakau instead of Kraków: "The name of Kraków disappeared from official letters. It must be Krakau, end of story. As a result [...] these announcements sound like a bizarre and macaroni oddity" (EdKub, 20.12.1941, p. 183).

Particularly striking are onomastic measures, consisting in a removal of the Polish names, which - as observed by the authors of the journals - have dis- 
appeared from official letters, replaced by names honouring leading figures or symbols of the Third Reich (above all Hitler's):

On the occasion of the first anniversary of the outbreak of the war, the Germans had a great celebration. The whole city was decorated with flags, and pl. Litewski [square name] was renamed Adolf Hitler Platz. This is what all prominent squares in the entire General Governorship are to be called (ReMosz, 1.09.1940, p. 138).

\subsection{The totalitarian discourse versus the anti-totalitarian discourse: Oppositional reading}

The authors of the journals, similarly to the editors of the Polish underground press, usually learned to read the Nazi totalitarian discourse at an aberrant/oppositional level (Stuart Hall's term), that is, in the context of the entirety of messages. The meanings used by the propaganda apparatus of the Third Reich are decoded within other discourses: mainly through the reception of their content against the background of knowledge obtained from the underground propaganda discourse or information transmitted by word of mouth. Various discursive images of the world collide in the journals (Czachur 2011). Although the official message evokes various emotions, and in the light of the occupation code, the media in the services of the occupant are generally boycotted, they have their intertextual presentation in the journals in the form of a commentary or a reading á rebours (cf. Cytowska 1986). A measure of communication practice, expressing the attitude towards the entire totalitarian discourse, turns out to be the written methods of accessing the "free word" (cf. Ignatowicz 2011), that is the space of "the anti-totalitarian discourse". They are primarily illustrated by numerous: (1) terms of media and information carriers: a hidden radio, illegally issued memoirs, several leaflets on a printing machine, illegal newsletters + read to shreds, copied on a duplicating machine, secret + radio messages/newsletters; (2) phrases depicting the act of communication: it is heard that...; get something illegal; learn, receive, speak + from a reliable source; (3) terms expressing the quality or cognitive value of these messages: certain 'trustworthy, reliable', verified news; confidential, but certain news, whispered talks, sometimes (4) taking the form of a metatextual game: existent or non-existent 'faked' facts, news with a 'made by England'stamp, 'interceptions from the BBC radio' (ZeWaś, 21.03.1941, p. 27).

Not only is the Hitlerite propaganda presented as a form of controlling the occupation society (and a tool for its degradation), but also as a tool of war social engineering. The journals focus on its most important functions: (1) distortive (based on the manipulation of meanings - by concealing or euphemizing 
widely known information, mainly on terror and war crimes); (2) emotional and impelling (employing methods of agitation or recurrent recruitment campaigns); (3) psychological (related to the control of moods and feelings of the collective addressee, based on fear), and finally (4) ritual/performative (aiming to consolidate in the public space the signs of Hitlerite ideology and symbols of power). The most important pragmatic properties of the act of receiving this discourse (mainly press publications in Polish, otherwise reptile press, rag press, rags/prasa gadzinowa, gadzinówki, szmattawce) are reconstructed in Table 1.

Table 1. Reception of Nazi totalitarian discourse by the authors of war diaries, chronicles

\begin{tabular}{|c|c|}
\hline $\begin{array}{l}\text { RECOGNIZED } \\
\text { FUNCTIONS AND } \\
\text { PROPERTIES } \\
\text { OF THE NAZI } \\
\text { TOTALITARIAN } \\
\text { DISCOURSE }\end{array}$ & $\begin{array}{l}\text { THEIR RECEPTION, DECODED MEANING } \\
\text { (or aberrant reception, following S. Hall) } \\
\text { Selected illustrations }\end{array}$ \\
\hline $\begin{array}{l}\text { 'Publications in } \\
\text { the services of the } \\
\text { occupant - formally } \\
\text { in Polish, a mock-up of } \\
\text { old Polish publishing } \\
\text { houses (newspapers)' }\end{array}$ & $\begin{array}{l}\text { "We do not have any Polish publications. Newspapers printed in } \\
\text { Polish in Warsaw, Kraków and Lublin are worse than German dailies } \\
\text { due to the tendency. I do not buy these newspapers as a rule and I do } \\
\text { not read them because I have utter disgust towards them" (ZKluk, } \\
\text { 1.09.1940, pp. 153-154). }\end{array}$ \\
\hline $\begin{array}{l}\text { 'Biased and } \\
\text { manipulative, because } \\
\text { they depict untruth/lie' }\end{array}$ & $\begin{array}{l}\text { "Sometimes an issue of Nowy Kurier Warszawski or Goniec } \\
\text { Krakowski falls into our hands, but these newspapers are so biased } \\
\text { that one cannot believe anything they write. Unless they are only } \\
\text { advertisements" (ZKluk, 26.01.1940, p. 98). }\end{array}$ \\
\hline $\begin{array}{l}\text { 'Presenting social } \\
\text { issues, they run } \\
\text { a recruitment campaign/ } \\
\text { action' }\end{array}$ & $\begin{array}{l}\text { "And the Germans constantly use the carrot and stick approach. Today } \\
\text { again, calls for works in Germany have been put up entitled 'This is } \\
\text { how a Polish worker lives in Germany"' (LLand, vol. 2, 16.02.1943, } \\
\text { p. 347). }\end{array}$ \\
\hline $\begin{array}{l}\text { 'They are a propaganda } \\
\text { tube for the use } \\
\text { of the occupation } \\
\text { authorities (General } \\
\text { Governorship)' }\end{array}$ & $\begin{array}{l}\text { "Today is this anniversary of the formation of the governorship [...] } \\
\text { The measure of this moment is the weight of the newspapers, which } \\
\text { today came in a terrible volume, full of pompous statements, long- } \\
\text { winded descriptions of the works made, and the most specific in all } \\
\text { this, the advertisements" (LLand, vol. 1, 25.10.1940, p. 763). }\end{array}$ \\
\hline $\begin{array}{l}\text { 'They agitate, use } \\
\text { aggressive rhetoric (of } \\
\text { hatred), and at the same } \\
\text { time cover up terror or } \\
\text { goals related to their } \\
\text { extermination policy' }\end{array}$ & $\begin{array}{l}\text { "Our local 'pet' - Frank — graced the pages of an issue of a Polish } \\
\text { newspaper [Nowy Kurier Warszawski - M.P.], which was edited in } \\
\text { an impressive and triumphant tone, with an interview of a similar } \\
\text { nature [...] in another one, a story of how well the population of } \\
\text { Warsaw is doing }[\ldots] \text { a radical improvement of sanitary conditions } \\
\text { by separating the Christian population from the Jewish [...] There is } \\
\text { only one peaceful place in the world - the governorship in its official } \\
\text { body" (LLand, vol. } 3,21.12 .1943, \text { p. } 497 \text { ). }\end{array}$ \\
\hline
\end{tabular}




\begin{tabular}{|c|c|}
\hline $\begin{array}{l}\text { 'It tries to legitimize } \\
\text { the hegemonic } \\
\text { authority, its policy, } \\
\text { in a belying form, } \\
\text { presenting a fictitious } \\
\text { picture of occupation } \\
\text { life' }\end{array}$ & $\begin{array}{l}\text { "German press in the governorship tries to create the impression that } \\
\text { life under German occupation is normalizing, and proves it either by } \\
\text { collecting and properly illuminating real facts, or using ordinary lies" } \\
\text { (LLand, vol. 1, 17.03.1940, p. 347); } \\
\text { "But in the 'Warschauer', there is a mood of undisturbed calm [...] } \\
\text { The national desk of that newspaper creates the impression that the } \\
\text { governorship is some Platonic state ruled by philosophers: nothing, } \\
\text { only read-outs!" (LLand, vol. 2, 26.10.1940, p. 10); } \\
\text { "Obviously, the German propaganda in Poland describes miracles" } \\
\text { (EdKub, 29.06.1941, p. 142). }\end{array}$ \\
\hline $\begin{array}{l}\text { 'It is dangerous, } \\
\text { because it creates } \\
\text { a fictitious, positive } \\
\text { image of the enemy } \\
\text { occupant' }\end{array}$ & $\begin{array}{l}\text { "That Warschauer newspaper [Warschauer Zeitung - M.P.] praises } \\
\text { again the occupant's activities in the field of labor and social welfare } \\
\text { [...] Of course, all that was bad was the fault of Poles, everything } \\
\text { good - Germans did it" (LLand, vol. 1, 2.04.1940, p. 383); } \\
\text { "The press propaganda regarding the benefaction provided by the } \\
\text { occupants continues" (LLand, vol. 1, 4.04.1940, p. 388). }\end{array}$ \\
\hline $\begin{array}{l}\text { 'It disseminates } \\
\text { patterns of negative } \\
\text { social behavior and } \\
\text { thus hits the morale of } \\
\text { the occupied society' }\end{array}$ & $\begin{array}{l}\text { - in terms of culture: "Life in Poland is prepared in the German } \\
\text { fashion" (EdKub, 11.06.1940, p. } 71 \text { ) } \\
\text { - in terms of political agitation: "It's funny how serious a role in } \\
\text { this German propaganda is played by Poland as an example of the } \\
\text { victim of Bolshevism; the same Poland that Germans try to remove } \\
\text { from the face of the earth" (LLand, 13.03.1943, p. 268) } \\
\text { - in terms of psychology: "And the Germans constantly use the } \\
\text { carrot and stick approach. Today again, calls for works in Germany } \\
\text { have been put up titled "This is how a Polish worker lives in } \\
\text { Germany" (LLand, vol. 2, 16.02.1943, p. 347). }\end{array}$ \\
\hline
\end{tabular}

Source: own work.

The totalitarian discourse is described not only as lying, biased and intrusive, but above all - as a practice that evokes reactions in the form of emotive and even aesthetic behavior, which is bluntly expressed in the Lublin occupation chronicle of the Moszyński family:

The whole city is covered with these large placards featuring an additional word "Victoria". The placards are in various colours. They can be found on houses, shops, carriages, windows, cars, and even on a dumpster standing at ul. Świętojańska, or a public toilet (ReMosz, 18.07.1941, p. 199)

\subsection{The image of the totalitarian propaganda and its evaluation}

The experience of the Hitlerite totalitarian propaganda, as well as its war version, results in the devaluation of the term that had neutral meanings prior to the war, identical primarily with a mass communication activity (e.g. as a superordinate of means and areas of mass communication: media, advertising), and secondarily - it was associated with forms (genres) of shaping public opinion 
or political activity by means of the conative function of language and expression (see Kamińska-Szmaj 2004). During the war the name propaganda is filled with components of connotative meanings, and what is more - the lexical field from which it originates is expanded with synonym substitutes, finding their designation in wartime events (e.g. psychological war, total war, counter-propaganda, diversion, recruitment action). The propaganda ritual expands the genological awareness of propaganda recipients - in this article: the authors of the journals.

Table 2. The image of 'Hitlerite propaganda in occupied Poland' by the war chronicles and diaries - main textual meanings

The Hitlerite propaganda in occupied Poland is:

[war aspect] 1. 'a tool of psychological war and symbolical violence'

[political 2. 'totally subordinated to the total power, serving to control life in the occupied aspect] country and to degrade the occupied society'

\section{It is characterized by the following:}

— 'it uses long-lasting and devised activities to stimulate': (new) propaganda/ recruitment action, agitation (carry out agitation among Poles)

— 'using various psychological means that affect the senses and emotions': noisy (advertisement, campaign)

[methods]

— 'and various genre forms': propaganda posters with inscriptions, silly rhyme, press propaganda, a new war slogan

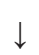

— 'based on intimidation strategies': the carrot and stick approach

— 'and thus meted out against something/someone': anti-Bolshevik propaganda

[goals] _ 'so that in the ritual form, legitimize the totalitarian (Hitlerite) power and fulfill all war benefits (of "the occupant") at the expense of its addresees ("the occupied")': German self-advertisement, "catchword of the day", staging propaganda, (lengthy and longish) speech, a psychology of the occupant-winner

Source: own work. 
In the general sense, an image of the totalitarian propaganda (in the studied perspective - Hitlerite propaganda) is created which was not a known phenomenon and which becomes a synonym substitute for negative communication phenomena: disinformation, lies, verbal and non-verbal aggression, as well as the institutionalized form of anti-dialogue and anti-communication communicative action, or manipulation (the term manipulation does not function in the war usage yet). On the basis of the source material it is possible to reconstruct its following definitional components - they refer to mass communication practices used by the Hitlerite apparatus in occupied Poland (see Table 2). Propaganda turns out to be a psychological weapon, so dangerous that it requires defensive actions. Such actions occurred in the institutionalized underground activity of the underground state (see, i.a.: Wolińska 1996; Jędrzejko 2006; Ignatowicz 2011; also Stępnik, Rajewski, eds., 2011; Poprawa 2017). War chronicles revealed a record of the communication awareness of their authors, created at the level of their own reflections and registration of signs originating from other areas of "the anti-totalitarian discourse". A "decoded, disarmed" picture of propaganda, "a totalitarian language sabotage" arises — as S. Balbus put it - (after: Język i polityka 1990: 49), containing not only the author's point of view, but also a record of the fight against terror at the linguistic level and communicational reflection. First of all, it has a depreciative character, as evidenced by numerous strategies for pejorative evaluation of propaganda (publications, contents, forms, decoded semantic and pragmatic phenomena), which I present in the table below. It presents the most important lexical and stylistic measures of a of an evaluative character: the names of propaganda activities, their ironic or pejorative (contemptuous) denominations and numerous metaphors expressing connotations about the entire act of propaganda communication. Among textual illustrations, quoted from chronicles, there are also textual activities of their authors, consisting of travesty of quotations (Bartmiński, NiebrzegowskaBartmińska 2009; Biardzka 2014), key words of LTI, mainly with the primary function of commentary or depreciation (see Table 3 ). 
Table 3. Names for the totalitarian propaganda — selected illustrations from war chronicles

\begin{tabular}{|l|}
\hline Selected linguistic means \\
\hline \multicolumn{2}{|c|}{ I. Names/terms for the media } \\
— neutral: newspapers printed in Polish; so- \\
called rag press, megaphone, (German) radio, \\
film \\
— pejorative, contemptuous: — rag, rag \\
presss, (Hitlerite +) pseudo-newspaper, reptile \\
press (of Warsaw/Kraków), sguawk box (of the \\
German radio) (szmata, szmattawiec, gazetka \\
+ hitlerowska, gadzinowiec, gadzinówka + \\
warszawska/krakowska, szczekaczka radia \\
niemieckiego) \\
- neologism coined from the names of Ger- \\
man dailies: krakauera, warschauerka
\end{tabular}

Selected illustrations

II. Names/terms for people responsible for the propaganda

"In addition to the issue of collecting quotas, to which today's 'filthy tabloid' devotes an insolent article [...] According to 'the rag', the resistance [of peasants - M.P.] will be broken anyway" (LLand, vol. 3, 21.03.1943, p. 156)

"In Warsaw, newspapers come out, the socalled reptile press, and the most popular press is whispered one" (LKrModz, p. 55)

"Squawk boxes talk about bombardment of Murmańsk [...] Varsovians gather daily at the Jabłkowscy store, listening to the news from the battlefield" (LKrModz, p. 50)

\begin{tabular}{|c|c|}
\hline \multicolumn{2}{|c|}{ II. Names/terms for people responsible for the propaganda } \\
\hline $\begin{array}{l}\text { epithets/invectives naming journalists: paid } \\
\text { hireling, susceptible brawler, traitor }\end{array}$ & $\begin{array}{l}\text { "Today, the notorious editor of the Przetom } \\
\text { debuted in the squawk box, calling Stalin and } \\
\text { Bolshevism names because of Warsaw, and } \\
\text { slandering the 'knuckleheads' of Polish and } \\
\text { English politicians. Oh, that propaganda will } \\
\text { always find some susceptible brawler or traitor } \\
\text { to fool the naive" (EdKub, } 4.09 .1944 \text {, p. } 341 \text { ) }\end{array}$ \\
\hline \multicolumn{2}{|c|}{ III. Valuating propaganda activities } \\
\hline $\begin{array}{l}\text { — marked synonyms of lies/manipulation: } \\
\text { trick, bluff } \\
\text { - expressions deriding a low level of jour- } \\
\text { nalism: nonsense, ridiculous arguments, after } \\
\text { proper processing, uses a platitude } \\
\text { - (quite frequent) word patterns revealing } \\
\text { pejorative assessment and negative emotions: } \\
\text { impudence and stupidity, mockery and insult } \\
\text { - collocations mocking an excess of forms } \\
\text { (sometimes ironic): full of generosity, pom- } \\
\text { pous, long-winded descriptions, intensification } \\
\text { of noise, the articles sound comical, oddity, } \\
\text { cheap grandiloquence } \\
\text { - epithets expressing revulsion (filthy }+ \text {...) } \\
\text { - epithets deprecating self-presenting behav- } \\
\text { ior: a cheer, a hit, braggart's escapade }\end{array}$ & $\begin{array}{l}\text { "In comparison to what is going on in the street } \\
\text { [terror, arrests and mass executions - M.P.], } \\
\text { the platitudes of "the filthy tabloid' do not } \\
\text { pose any danger as a rag propaganda" (LLand, } \\
\text { vol. } 3,21.10 .1943, \text { p. 334) } \\
\text { "Germans are insolent enough to glue the post- } \\
\text { er calling for a fight against Bolshevism, and } \\
\text { in a special issue of the wall newspaper to en- } \\
\text { courage Poles to do so with alleged examples } \\
\text { of other nations! However, there is more fool- } \\
\text { ishness in this than insolence" (LLand, vol. 2, } \\
8.04 .1943, \text { p. 326) }\end{array}$ \\
\hline
\end{tabular}




\section{Metaphorical names for the act of propaganda communication}

- 'auditive metonymies as a substitute for verbum dicendi': it screams, yells, blows in a trombone, trumpets, sends opinions, noises

— 'movement metaphors': it started to operate in full swing, developed with all energy

- personifications based on negative sensory impressions: it exudes, rages, still make the most of, a propaganda wave arrives, it brings a sensation that is painful for us

- other marked personifications: has a sour face, a lot of irritation, plays on the moods/ on the strings of human hatred, something disturbs the German press, pours crocodile tears of compassion, fools, falsifies, loses control of the situation, constantly murmurs something
"The conference with American statesmen Bullit and Kennedy spoils the mood in the 'Krakauer', which shouts about American fomenters" (EdKub, 12.04.1940, p. 58)

"Sends opinions through noisy loudspeakers, which now, because of the German propaganda, have been installed in the Planty Park" (EdKub, 4.05.1943, p. 281)

"The German propaganda because of Kharkiv's recapture blows in a trombone" (EdKub, 18.03.1943, p. 265)

"The change of the cabinet in France seems to be beneficial, judging from the rage of the Goniec [Goniec Krakowski - a daily published in Polish - M.P.]" (BrBobr, 25.03.1940, p. 55)

"Here in the city, the propaganda of all kinds of posters spreads under the catchword: 'A shovel is our weapon!"” (EdKub, 29.09.1944, p. 344)

"The 'Krakauer' has a sour face because Turkey is being drawn to the American side" (EdKub, 7.12.1941, p. 180)

Source: own work.

\section{Summary}

The totalitarian Nazi discourse basically reflected the entire policy of the occupant, the practice of exercising uncontrolled power and the intention of total domination, based on the uncontrolled "divide and conquer" principle. This discourse - primarily realized with the aid of a total and completely monopolized, top-down controlled (by means of offices subordinate to Goebbels), simplified propaganda (in other words, unified by force) - spoke with clichéd catchwords, aggressive rhetoric and brutal language. It revealed itself as a form of control (oppression) as well as symbolic violence. First of all, it created a vision of "a model citizen of the General Governorship" - slavishly working for the "German reconstruction effort in the East" (cf. Woźniakowski 2014; Głowiński 2000), and second of all, it reminded of "the power of the German army" every step of the way and thus, it was supposed to paralyze the collective mood of Poles related to the end of the war and a return to the pre-war reality (cf. Chrobaczyński 2015), and - as a form of "psychological war" - demobilize (both in a figurative and 
real sense, cf. Welch 2003). Tools of mass influence, typical of both the LTI and Goebbels' propaganda, stood out, such as: (a) simplified and repetitive topics and form, (b) language affecting emotions (usually causing fear in the recipient), and (c) a method of constantly repeating the same statements in extended genre variants (from catchwords, through leaflets and posters to film chronicles) (cf. Ociepka 1999), evoking the impression of "ubiquitous propaganda" (Kołtunowski 1990). In terms of semantics and pragmatics, communication practices of Hitlerite authorities reflected all model features of the totalitarian discourse, among which - after Głowiński (1996) - one can indicate: (1) the dominant modal frame of "an order" - at the expense of a subdued (or absent) persuasive function; (2) devoiding the addressee of subjectivity - that is, directing the message to "a passive recipient"; (3) the use of simplified axiology and arbitrary meanings (transformed into non-predicative judgments and catchwords); and (4) the ubiquitous category of "the enemy", based on prejudices and conspiracy theories. The latter included various political invectives and, above all, content of racist ideology taking the form of dehumanizing words and presuppositions concerning acts of violence (genocide, extermination, Holocaust).

The propaganda was decoded and ridiculed: the society, although not from the beginning, as shown by the material presented, learned to read it instrumentally (drawing hidden meanings or real information), and above all oppositionally - from boycott to mockery. The journal entries primarily indicate two dominants of the entire discursive order imposed by the Third Reich: the preservation of negative emotions in the public sphere (relevant to war and occupation policy), but also of the foreign semantic universe. The journals do not include testimonies indicating that the propaganda content had been assimilated in accordance with the intentions of the sender. This was a result of the universal collective attitude towards the occupant - treated as an enemy, an invader, of the social code and underground counter-propaganda, as well as of the ability to compile real facts with the reality created in the media in the services of the occupation authorities.

We encounter in the analyzed journals (chronicles) a fully oppositional reception - from reflection to dissent. Nevertheless, it should be noted that the peace of the journal writers is disturbed not only by "what and how something was communicated", but also by the very fact that it was "communicated" — in an aggressive or intrusive way for that matter. First of all, the propaganda - by acting ritually, repetitively and massively — "clouded" the public space (Nowak 2008) and caused confusion. In addition - apart from manipulations and lies, it created facts (today one might say "factoids") — it acted in an aggressive way since it allowed into the official circulation catchwords, slogans and content characteristic of the LTI. Although in the narrative of the studied journals they usually include a metatextual commentary, they function in these chronicles like "a foreign body" — as Wierzbicka would say. Each cited item has inverted commas or a functionally similar metatextual operator, as for example: (1) numerous synonyms of the 
subject recognized in Nazi propaganda as an enemy (political and war): "warmonger", "bandit" 'everyone in the LTI called as an enemy'; (2) especially catchwords from the statements of representatives of the Nazi authorities (often noted from reading slogans, press headlines and other intertextual forms: 'a periphrasis of General Governorship in speeches of H. Frank'; (3) fixed catchwords of the war propaganda, expressing triumphalism and an intention to intimidate the civilian population (Poles in the occupied country): "Victoria", the letter " $V$ ". Nevertheless, it has to be added that the language of this propaganda (at the level of fuzzy references) allowed into the mass circulation a collection of biases and clichés characteristic of the LTI, but also an entire group of labels and ideologemes, which in other functional version had their use in the entire war and occupation discourse (e.g. fomenters, sanation clique, schemers and sanation patriots, imperialism + of sth, international caste, the government led us to destruction, red terror, Bolshevik + any designation, sickle and hammer). There was an interference of various propaganda codes, as some of the lexemes - in a different reference and in other pragmatic conditions - appeared as labels in the underground conspirative discourse, aimed against "a political enemy" (cf. Wolińska 1992, 1996; Poprawa 2016a), returned in a similar textual form, but in a different semantic frame and from another source, that is in "the newspeak" (cf. the structure of the labels/invectives noted here with the ones in the work of Nowak 2002: 131).

The Nazi propaganda in occupied Poland mainly used various forms of hate rhetoric, primarily highlighting in the public space (virtually everywhere and in every intrusive form) different lexical/textual variants of racist anti-Semitic catchwords (many such examples are present in the chronicles of Ludwik Landau and Remigiusz Moszyński). It should be added that in its own contexts, this propaganda also used anti-Semitic phrases from pre-war Polish publishing houses (here are some examples from the research materials: Judeo-Poland, Judeo-Polonia, the Jewish matter, Jewish-Freemasonry, Judeo-Communism (cf. Kamińska-Szmaj 1994; Polkowska 2015; Michlic 2015; Kuciński, Krzywiec, eds., 2011). These extracts from Polish pre-war texts, prepared by journalists of the by journalists of the German "reptile press", and containing, and containing a negative, propaganda image of the Jew, as well as fragments of anti-Semitic ideological texts (for example, originating from publications of nationalistic and fascistic groups) - in a new intertextual version positioned themselves next to the whole bunch of presuppositions that refer to the darkest concept of the Nazi doctrine, namely the Endlösung ('the final solution').

In terms of communication, the Polish language defended itself against the impact of the totalitarian discourse, since the catchwords and linguistic ritualisms characteristic of "the occupation version of the LTI" did not become established, while "the anti-totalitarian discourse" and its underground propaganda created "a language self-defense mechanism". However, at the level of reflection on communication ethics, it should be remembered that words and communication strat- 
egies exist which should never find their contemporary updates, since they will always be a sign of an experience that history warns against.

\section{Bibliography}

Allert T. (2008), Niemieckie pozdrowienie. Historia fatalnego gestu, transl. B. Baran, Warszawa. Arendt H. (2008), Korzenie totalitaryzmu, transl. D. Grinberg, Warszawa.

Balbus S. (1990), “Słowa i desygnaty czy akty i gatunki mowy?", Teksty Drugie, no 2.

Bajerowa I. (ed.) (1996), Język polski czasu drugiej wojny światowej (1939-1945), Warszawa.

Bajerowa I. (2003), Zarys historii języka polskiego 1939-2000, Warszawa.

Barański J. (2001), Socjotechnika - między magia a analogia, Kraków.

Barker Ch. (2005), Studia kulturowe. Teoria i praktyka, transl. A. Sadza, Kraków.

Bartmiński J., Niebrzegowska-Bartmińska S. (2009), Tekstologia, Warszawa.

Bartoszewski W. (1987), Na drodze do niepodległości, Paryż.

Biardzka E. (2014), Przytaczanie w prasie codziennej, Wrocław.

Bralczyk J. (2001), O języku polskiej propagandy politycznej lat siedemdziesiatych, Warszawa.

Butler J. (2010), Walczace stowa. Mowa nienawiści i polityka performatywu, transl. A. Ostolski, Warszawa.

Butler J. (2011), Ramy wojny. Kiedy życie godne jest optakiwania?, transl. A. Czarnacka, Warszawa.

Chrobaczyński J. (2015), Dwie klęski. Wrześniowy syndrom 1939 i klęski Francji 1940 w postawach, zachowaniach i nastrojach spoleczeństwa polskiego. Próba retrospekcji i komparatystyki. Kontrowersje i dylematy, Kraków.

Cytowska E. (1986), Szkice z dziejów prasy pod okupacją niemiecka (1939-1945), Warszawa-Łódź.

Czachur W. (2011), "Dyskursywny obraz świata. Kilka refleksji”, Tekst i Dyskurs - Text und Diskurs, no. 4.

Czerwiński M. (2015), Kultura - dyskurs - znak, Kraków.

Czyżewski M. (2002), "Etnometodologia”, [entry in:] Encyklopedia socjologii. Suplement, ed. W. Kwaśniewicz, Warszawa.

Dijk van T.A. (ed.) (2001), Dyskurs jako struktura i proces, transl. G. Grochowski, Warszawa.

Dobek-Ostrowska B., Fras J., Ociepka B. (eds.) (1999), Teoria i praktyka propagandy, Wrocław.

Dytman-Stasieńko A. (2006), Święto zawłaszczonych znaczeń. 1 Maja w PRL. Ideologia, rytuat, język, Wrocław.

Ferenc T., Dymarczyk W., Chomczyński P. (eds.) (2011), Socjologia wizualna w praktyce. Plakat jako narzędzie propagandy wojennej, Łódź.

Filar D., Piekarczyk D. (2013), Narracyjność języka i kultury. Literatura i media, Lublin.

Filipkowski P. (2010), Historia mówiona i wojna. Doświadczenie obozu koncentracyjnego w perspektywie narracji biograficznej, Wrocław.

Fras J. (2006), Komunikacja polityczna. Wybrane zagadnienia gatunków i języka wypowiedzi, Wrocław.

Garlicki J., Noga-Bogomilski A. (2004), Kultura polityczna w społeczeństwie obywatelskim, Warszawa.

Głowiński M. (1990), Nowomowa po polsku, Warszawa.

Głowiński M. (1995), "Mowa i zło", [in:] M. Głowiński, Pismak 1986 i inne szkice o różnych brzydkich rzeczach, Warszawa.

Głowiński M. (1996), “O dyskursie totalitarnym”, [in:] O zagrożeniach i bogactwie polszczyzny, ed. J. Miodek, Wrocław.

Głowiński M. (2002), "Mowa agresji”, [in:] Człowiek i agresja. Głosy o nienawiści i przemocy. Ujęcie interdyscyplinarne, ed. S. Amsterdamski,Warszawa. 
Głowiński M. (2007), "Retoryka nienawiści”, Nauka, no. 2.

Głowiński T. (2000), O nowy porządek europejski. Ewolucja hitlerowskiej propagandy politycznej wobec Polaków w Generalnym Gubernatorstwie 1939-1945, Wrocław.

Goban-Klas T. (2005), Media i komunikowanie masowe. Teorie i analizy prasy, radia, telewizji i Internetu, Warszawa.

Gorman L., McLean D. (2010), Media i społeczeństwo, transl. A. Sadza, Kraków.

Grębowiec J. (2013), Mówić i działać. Wykłady z pragmatyki języka, Wrocław.

Grzmil-Tylutki H. (2010), Francuska lingwistyczna teoria dyskursu, Kraków.

Hałas E. (2007), Symbole i społeczeństwo. Szkice z socjologii interpretatywnej, Warszawa.

Howarth D. (2008), Dyskurs, transl. A. Gąsior-Niemiec, Warszawa.

Ignatowicz A. (2011), "Formy i metody oddziaływania propagandowego Armii Krajowej na społeczeństwo polskie w drugiej połowie 1943 roku", [in:] Komunikowanie się Polaków w okresie II wojny światowej, eds. K. Stępnik, M. Rajewski, Lublin.

Jacko F.J. (2008), "Ewokatywna, sugestywna i perswazyjna funkcja symboli propagujących ideologię", [in:] Ideologie w stowach i obrazach, eds. I. Kamińska-Szmaj, T. Piekot, M. Poprawa, Wrocław.

Jarecka U. (2008), Propaganda wizualna stusznej wojny. Media wizualne XX wieku wobec konfliktów zbrojnych, Warszawa.

Jastrzębski Z. (1986), Poetyka humoru lat okupacji, Warszawa.

Jędrzejko E. (1996), “Język satyry okupacyjnej”, [in:] Język polski czasu drugiej wojny światowej (1939-1945), ed. I. Bajerowa, Warszawa.

Język i polityka (1990), Teksty Drugie. Dwumiesięcznik Instytutu Badań Literackich PAN, no. 4.

Kalisz R. (1993), Pragmatyka językowa, Gdańsk.

Kamińska-Szmaj I. (1994), Judzi, zohydza, ze czci odziera. Język propagandy politycznej w prasie 1919-1923, Wrocław.

Kamińska-Szmaj I. (2004), "Propaganda — perswazja — manipulacja. Próba uporządkowania pojęćc, [in:] Manipulacja w języku, eds. P. Krzyżanowski, P. Nowak, Lublin.

Kamińska-Szmaj I. (2011), „Język polityki czy styl/ dyskurs polityczny”, [in:] Dyskursy trzeciego tysiaclecia, ed. E. Pajewska, Szczecin.

Kamińska-Szmaj I. (2013), "Komunikacja polityczna — język, styl, dyskurs”, [in:] Style wspótczesnej polszczyzny. Przewodnik po stylistyce polskiej, eds. E. Malinowska, J. Nocoń, U. ŻydekBednarczuk, Kraków.

Kamińska-Szmaj I. (2017), Język polskiej lewicy. Od Wielkiego Proletariatu do końca PRL, Wrocław.

Kania S. (1986), Polska gwara konspiracyjno-partyzancka, Warszawa.

Karwat M. (2014), Podstawy socjotechniki dla politologów i nie tylko, Warszawa.

Kiklewicz A. (2007), "Ideologie w tekście publicystycznym. Kategorie tematyczne, konceptualizacje metaforyczne, wartościowania”, Zeszyty Prasoznawcze, no. 3-4.

Kleszczowa K. (1996a), “Odbicie rzeczywistości wojennej i okupacyjnej w leksyce języka ogólnego", [in:] Język polski czasu drugiej wojny światowej (1939-1945), ed. I. Bajerowa, Warszawa.

Kleszczowa K. (1996b), "Sytuacja języka polskiego w Generalnej Guberni”, [in:] Język polski czasu drugiej wojny światowej (1939-1945), ed. I. Bajerowa, Warszawa.

Kołtunowski P. (1990), Strategie propagandy hitlerowskiej w Generalnym Gubernatorstwie na podstawie “Krakauer Zeitung” (1939-1945). Studium historyczno-filologiczne, Lublin.

Król E.C. (2010), Polska i Polacy w propagandzie narodowego socjalizmu w Niemczech 1919-1945, Warszawa.

Król E.C. (2015), "W poszukiwaniu modelu propagandy totalnej”, [in:] Propaganda w systemach demokratycznych i niedemokratycznych, ed. J.W. Wołoszyn, Lublin.

Kuciński P., Krzywiec G. (eds.) (2011), Analizować nienawiść. Dyskurs antysemicki jako tekstowe wyzwanie, Warszawa.

Kula H.M. (2005), Propaganda współczesna. Istota - właściwości, Toruń. 
Leociak J. (2016), Tekst wobec Zagłady. O relacjach z getta warszawskiego, Toruń.

Lewandowska S. (1992), Prasa okupowanej Warszawy 1939-1945, Warszawa.

Madajczyk C. (1970), Polityka III Rzeszy w okupowanej Polsce, vol. 1-2, Warszawa.

Majewski P. (2015), Wojna i kultura, Warszawa.

Marcuse H. (2003), "Język administracji totalnej”, [in:] Antropologia słowa. Zagadnienia i wybór tekstów, ed. G. Godlewski, Warszawa.

Matkowska E. (2012), Propaganda w NRD. Media i literatura, Wrocław.

Michlic J.B. (2015), Obcy jako zagrożenie. Obraz Żyda w Polsce od 1890 roku do czasów obecnych, Warszawa.

Mrozowski M. (2001), Media masowe. Władza - rozrywka - biznes, Warszawa.

Niewiara A. (2010), Ksztalty polskiej tożsamości. Potoczny dyskurs narodowy w perspektywie etnolingwistycznej (XVI-XX wiek), Katowice.

Nowak P. (2002), SWOI i OBCY w językowym obrazie świata, Lublin.

Nowak P. (2008), "Retoryka a propaganda polityczna", [in:] Retoryka, eds. M. Barłowska, A. Budzyńska-Daca, P. Wilczek, Warszawa.

Nowakowska A. (2008), "Semantyka barw w służbie ideologii”, Oblicza Komunikacji 1, Ideologie w słowach i obrazach, eds. I. Kamińska-Szmaj, T. Piekot, M. Poprawa, Wrocław.

Ociepka B. (1999), “Aneks: Propaganda w Trzeciej Rzeszy”, [in:] Teoria i praktyka propagandy, eds. B. Dobrek-Ostrowska, J. Fras, B. Ociepka, Wrocław.

Ogonowska A. (2004), Przemoc ikoniczna. Zarys wykładu, Kraków.

Ostrowski M. (2010), "Język mediów a rzeczywistość faszystowska w świetle działalności prasy gadzinowej w Polsce w latach 1939-1945”, [in:] Styl - dyskurs - media, eds. B. Bogołębska, M. Worsowicz, Łódź.

Ożóg K. (2014), "Rytualizacja w języku władzy komunistycznej PRL”, Oblicza Komunikacji 7 , Język polityki-historia i wspótczesność.

Pacuła J. (2012), "Słowa w natarciu. Metaforyka militarna w dyskursie publicznym”, Zeszyty Prasoznawcze, no. 3.

Piekot T. (2006), Dyskurs polskich wiadomości prasowych, Kraków.

Pisarek W. (ed.) (2006), Stownik terminologii medialnej, Kraków.

Pisarek W. (2008), Wstęp do nauki o komunikowaniu, Warszawa.

Pluta F. (1975), Język polski w okresie II wojny światowej. Studium słowotwórczo-semantyczne, Opole.

Polkowska L. (2015), Język polskiej prawicy, Warszawa.

Poprawa M. (2012), "Badania dyskursu publicznego w świetle stylistyki polskiej — tradycja, teraźniejszość, perspektywy”, Oblicza Komunikacji 5. Analiza dyskursu centrum-peryferie, Wrocław.

Poprawa M. (2016a), "Inwektywy czasów II wojny światowej. Językowe środki obrażania przeciwnika/wroga politycznego w prasie konspiracyjnej lat 1939-1945", Oblicza Komunikacji 9 , Medialne i propagandowe oblicza wojny.

Poprawa M. (2016b), "Plotka i pogłoska jako specyficzny akt komunikacji wojennej”, [in:] Lingua et gaudium. Ksiega jubileuszowa ofiarowana Profesorowi Janowi Miodkowi, eds. M. Misiak, M. Zaśko-Zielińska et al., Wrocław.

Poprawa M. (2017), "Prasa konspiracyjna w służbie kontrpropagandy — funkcje, cele, zjawiska językowe (na przykładzie gazet podziemnych 1939-1945)", Oblicza Komunikacji 10, Obrazy wojny w mediach, pamięci i języku.

Post M. (2014), “Akty i gatunki mowy. Próba wielopłaszczyznowego zbliżenia”, [in:] Pragmatyka, retoryka, argumentacja. Obrazy języka i dyskursu w naukach humanistycznych, eds. P. Stalmaszczyk, P. Cap, Kraków.

Pratkanis A., Aronson E. (2008), Wiek propagandy. Używanie i nadużywanie perswazji na co dzień, transl. J. Radzicki, M. Szuster, ed. K. Skarżyńska, Warszawa. 
Reisigl M. (2010), „Dyskryminacja w dyskursach”, transl. D. Przepiórkowska, Tekst i Dyskurs Text und Diskurs, no. 3.

Rodak P. (2006), "Wojna i zapis. O dziennikach wojennych”, [in:] Wojna. Doświadczenie i zapis: nowe źródła, problemy, metody badawcze, eds. S. Buryła, P. Rodak, Kraków.

Rothenbuhler E.W. (2003), Komunikacja rytualna. Od rozmowy codziennej do ceremonii medialnej, transl. J. Barański, Kraków.

Scott J. (2006), Władza, transl. S. Królak, Warszawa.

Skowronek B. (2013), Mediolingwistyka. Wprowadzenie, Kraków.

Stelmach K. (2014), "Mediatyzacja propagandy — propagandyzacja mediów: wczoraj i dziś", Zeszyty Prasozanwcze, no. 2.

Stępnik K., Rajewski M., (eds.) (2011), Komunikowanie się Polaków w okresie II wojny światowej, Lublin.

Szarota T. (1988), Okupowanej Warszawy dzień powszedni. Studium historyczne, Warszawa.

Sztompka P. (2008), “Życie codzienne — temat najnowszej socjologii”, [in:] Socjologia codzienno$s ́ c i$, eds. P. Sztompka. M. Bogunia-Borowska, Kraków.

Tokarski R. (2004), “Manipulacja to zniewalanie. A cóż począć z 'urodzonymi w niewoli’?”, [in:] Manipulacja w języku, eds. P. Krzyżanowski i P. Nowak, Lublin.

Warchala J. (2016), "O pewnych warunkach perswazji”, Artes Humanae 1.

Wasilewski J. (2007), Retoryka dominacji, Warszawa.

Wesołowska D. (1996), Stowa z piekła rodem. Lagerszpracha, Kraków.

Wierzbicka A. (1990), "Język antytotalitarny w Polsce; o pewnych mechanizmach samoobrony językowej", Teksty Drugie, no. 4.

Winstone M. (2015), Generalne Gubernatorstwo. Mroczne serce Europy Hitlera, transl. T. Fiedorek, Poznań.

Witosz B. (2009), Dyskurs i stylistyka, Katowice.

Wojtak M. (2010), "Styl dziennikarstwa prasowego w perspektywie dyskursowej”, [in:] Styl — dyskurs - media, eds. B. Bogołębska, M. Worsowicz, Łódź.

Wolińska O. (1996), “Język polski w walce”, [in:] Język polski czasu drugiej wojny światowej (1939-1945), ed. I. Bajerowa, Warszawa.

Woźniakowski K. (1997), W kręgu jawnego piśmiennictwa literackiego Generalnego Gubernatorstwa (1939-1945), Kraków.

Woźniakowski K. (2014), Polskojęzyczna prasa gadzinowa czasów okupacji hitlerowskiej 19391945, Kraków.

Wyrwas K. (2014), Opowiadanie potoczne w świetle genologii lingwistycznej, Katowice.

Zaśko-Zielińska M. (2002), Przez okno świadomości. Gatunki mowy w świadomości użytkowników języka, Wrocław.

Zemszał P. (2016), Ojciec, wódz, nauczyciel. Nominacje językowe dotyczace Stalina w sowieckim dyskursie ideologicznym $w$ okresie powojennym, Toruń.

\section{Primary sources: Journals and war chronicles (with abbreviations)}

[BrBobr] — Bronisława Bobrowska, Notatki z czasów okupacji, Biblioteka Ossolineum, rkp., sygn. 13140.

[MaBobrz] - Maria Bobrzyńska z Peygertów, Życie zmiennym jest. Pamiętnik z lat 1900-1958, t. 3, 1939-1945, Biblioteka Ossolineum, rkp., sygn. 13533.

[ZKluk] — Zygmunt Klukowski, Dziennik z lat okupacji Zamojszczyzny (1939-1944), Lublin 1959. 
[LKrobModz] — Ludmiła Krobicka-Modzelewska, Warszawa 1939-1945, Biblioteka Ossolineum, rkp., sygn. 14083.

[EdKub] - Edward Kubalski, Niemcy w Krakowie, Dziennik 1 IX 1939-18 I 1945, ed. J. Grabowski, Z. Grabowski, Kraków-Budapeszt 2010.

[LLand] — Ludwik Landau, Kronika lat wojny i okupacji, t. 1-3, Warszawa 1962.

[ReMosz] — Remigiusz Moszyński, Dziennik 1939-1945. Wojna i okupacja w Lublinie w oczach dorostych i dzieci, Lublin 2014.

[HaReg] — Halina Regulska, Dziennik z oblężonej Warszawy, Warszawa 1978.

[StRemb] — Stanisław Rembek, Dziennik okupacyjny, Warszawa 2000.

[ZeWaś] — Zenon Waśniewski, Dziennik wojenny, Chełm 2011.

[KWyk] — Kazimierz Wyka, Życie na niby, Kraków 2010.

\section{Propaganda as a weapon and a tool of totalitarian power: The image of the concept in the common discourse of the war and occupation years (1939-1945)}

\section{Summary}

The author of the article describes the ways of conceptualizing Nazi totalitarian propaganda during the Second World War (1939-1945) in occupied Poland. This totalitarian discourse created many defense mechanisms on the level of colloquial knowledge, humor directed against the occupant, and was the object of counter-propaganda activities conducted by Polish underground organizations. This article describes a fragment of the "anti-totalitarian discourse" that emerges from the diaries and journals of the period described.

Keywords: totalitarian discourse, war propaganda, common discourse of the war and occupation years (1939-1945)

Translated by Krzysztof Wróblewski 